\title{
Relationship of Workaholism with Teachers' Organizational Commitment and Organizational Citizenship Behavior
}

\author{
Fatemeh Rakhshanimehr ${ }^{1}$, Hossein Jenaabadi ${ }^{*}$ \\ ${ }^{1}$ Department of Psychology, Zahedan Branch, Islamic Azad University, Zahedan, Iran \\ ${ }^{2}$ Faculty of Educational Sciences and Psychology, University of Sistan and Baluchestan, Zahedan, Iran \\ Email: ${ }^{\text {hjenaabadi@ped.usb.ac.ir }}$
}

Received 17 May 2015; accepted 5 July 2015; published 17 September 2015

Copyright (C) 2015 by authors and Scientific Research Publishing Inc.

This work is licensed under the Creative Commons Attribution International License (CC BY).

http://creativecommons.org/licenses/by/4.0/

(c) () Open Access

\begin{abstract}
Teachers voluntarily dedicate a lot of time to their vocational activates. This can lead to workaholism and may result in organizational commitment and organizational citizenship behavior. The main objective of the current study was to investigate the relationship of workaholism with organizational commitment and organizational citizenship behavior of teachers in Zahedan. This was a descriptive-correlational study. The sample included 300 teachers in Zahedan who were selected through applying stratified random sampling method and were examined using questionnaires on workaholism, organizational commitment, and organizational citizenship behavior. To analyze the obtained data, correlation coefficient and simultaneous multiple regression analysis were applied using SPSS $_{21}$. The obtained results indicated that teachers' mean scores on workaholism, organizational commitment and organizational citizenship behavior were higher than the considered theoretical mean. Workaholism and its components (feeling of being driven to work, work involvement, and work enjoyment) were significantly and positively related to organizational commitment and organizational citizenship behavior $(p<0.01)$. Moreover, the results of simultaneous multiple regression analysis indicated that components of workaholism could predict teachers' organizational commitment and organizational citizenship behavior $(p<0.05)$.
\end{abstract}

\section{Keywords}

Workaholism, Organizational Commitment, Organizational Citizenship Behavior, Teachers, Zahedan

\section{Introduction}

The term "workaholism" was first used in 1968 by Wayne Oates, an American pastor and psychologist, in his

*Corresponding author.

How to cite this paper: Rakhshanimehr, F., \& Jenaabadi, H. (2015). Relationship of Workaholism with Teachers' Organizational Commitment and Organizational Citizenship Behavior. Psychology, 6, 1469-1477.

http://dx.doi.org/10.4236/psych.2015.612144 
book entitled "Confessions of a Workaholic”. In his point of view, workaholics are those whose need to work is so extreme that may cause serious threats to their health, personal happiness, interpersonal relationships and social responsibilities and roles since they have an irrational commitment to work hard and they voluntarily devote a great amount of time to their work (Snir \& Harpaz, 2004). Spence and Robbins (1992) offered the first academic and practical definition of the term “workaholism”. From their perspective, workaholism originates from a series of people's attitudes and perceptions. They consider a person workaholic when he/she is highly involved with his/her work, has extraordinary inner compulsion to work hard and scantly enjoys his/her work. Snir and Harpaz (2004) defined workaholism as dedicating a great amount of time to physical and/or mental activities related to work. By the way, it is essential that various organizations realize the special characteristics of these people.

According to the typology, Spence and Robbins (1992) characterized workaholism by the amount and degree of the following components: 1 . Work involvement, 2. Feeling of being driven to work, and 3. Work enjoyment. In workaholics, the degree of work involvement is really high and they are really eager to work; however, they barely enjoy their work. In contrast, people who are eager to work are involved with their work and enjoy it; however, they do not have any excessive tensions towards it. Scott, Moore, and Miceli (1997) identified three workaholism patterns including compulsive-dependent, perfectionist, and achievement-oriented. Compulsivedependent workaholics experience a lot of anxiety and stress. Their work causes various physical and psychological problems. These people have low levels of satisfaction with their life and job and have low job performance. Perfectionist workaholics experience a high level of stress, mental and physical problems, establish hostile and ineffective interpersonal relations, have many absents and turnovers and have low job satisfaction and job performance. Finally, achievement-oriented workaholics have high levels of job satisfaction, life satisfaction, mental and physical health, job performance and organizational citizenship behavior and they have low stress and low voluntarily turnovers.

One of the most important characteristics of human resources which can cause a competitive advantage for organizations is their organizational commitment. According to Porter et al., organizational commitment is individuals' link with the organization which is characterized by three factors: a strong belief in and acceptance of the goals and values of the organization, willingness to work hard for the organization, and a strong desire to stay in the organization (As cited in Ebili and Nastizaee, 2009). Therefore, organizational commitment is a concept that indicates to what extent an employee adapts himself/herself to an organization's goals, values membership in that organization and tends to make all possible efforts to achieve overall goals of the organization. In this respect, commitment varies from being a member of an organization, since organizational commitment requires establishing active relations between employees and the organization, so that, with an inner desire, employees go beyond predetermined behaviors and aid the organization with playing a more active role in achieving the goals of the organization. Conducted studies have indicated that employees who are interested in and committed to the organization have higher performance and efficiency, are willing to stay in the organization, have less absenteeism, have higher incentive, and they are fully in accordance with the organization's changes (Madani \& Zahedi, 2005).

Despite various categories proposed for organizational commitment, the most applicable model, in this regard, is the three-dimensional model of Allen and Meyer (1990). This three-dimensional model of organizational commitment includes affective commitment, continual commitment, and normative commitment. Affective commitment indicates an individual's emotional attachment to the organization. This type of organizational commitment is really close to attitudinal commitment and is defined as attachment and dependence to the organization through accepting its values and desire to stay in the organization. Continual commitment includes the expected costs of leaving the organization, i.e. an individual's desire to stay in the organization indicates that he/she needs that job and cannot do any other jobs. The more an individual's investment in the organization, the less the probability of leaving his/her work. In this regard, the degree of one's commitment (i.e. desire to stay) increases. Moreover, the more an individuals' years of service, the more the probability of staying in the organization, preserving what he/she has worked for in all those years. Normative commitment demonstrates the necessity and a sense of duty to stay in the organization. This type of commitment refers to an employee's sense of obligation to continue his/her work at the organization due to the pressure exerted on him/her by others. Those who have a high degree of normative commitment are worried about leaving their work and how other people judge them. These people do not want to upset their manager or employer and are worried that their resignation would create a negative attitude towards them (Greenberg \& Bourne, 2000, as cited in Afkhami Ardakani \& Farahi, 2012). 
Another striking and significant feature of today's organizations is organizational citizenship behavior. Organizational citizenship behavior (OCB) is a behavior which is formed based on personal discretion and is not a part of job requirements; however, it increases an organization's effectiveness on satisfying the interests of stakeholders (Robbins, 2007). This is a wise behavior which aids colleagues, supervisors and the organization. Assisting new colleagues, not abusing colleagues, not exploiting colleagues, not using too much time to rest, participating in organizational meetings voluntarily, and withstanding some pressures caused by the organization are some manifestations of organizational citizenship behavior (Bennett \& Masholder, 1997). Employees committed to organizational citizenship behavior display some behaviors including aiding behaviors, magnanimity and forgiveness, organizational faithfulness, following the instructions, individual innovation, conscientiousness, personal development, politeness and consideration, civil behaviors and altruism (Podsakoff, Mackenzie, Paine, \& Bachrach, 2000). Employees who have organizational citizenship behavior like committed citizens attempt to promote the organization and work for it without any expectations. Naturally, if an organization has benefited from such employees, it does not have any concerns about its effectiveness and can compete with peace of mine and invest in other areas affecting its effectiveness. When benefiting from such employees, managers spend most of their time to matters other than those related to the duties of their subordinates (Organ, 1998). Teachers' organizational citizenship behavior can play a significant role in helping students, other teachers, school as a whole, competence and personal growth, classroom management, managers, and parents (Zeinabadi et al., 2008).

Considering what was mentioned earlier, it can be stated that human capital is the most important resource in an organization and the two significant and outstanding characteristics of employees, especially in educational organizations, are organizational commitment and organizational citizenship behavior which can be influenced by several factors. In the present study, the role of workaholism on these factors is examined. Therefore, the main objective of the current study is to investigate what the relationship of workaholism with organizational commitment and organizational citizenship behavior of teachers is in Zahedan.

\section{Methods}

This was a descriptive-correlational study (using regression). The statistical population included all high school teachers in Zahedan in the academic year 2014-2015. According to the statistics of the Department of Education in Zahedan, the number of high school teachers was 1353 individuals (807 female teachers and 546 male teachers). Using cluster and stratified random sampling methods proportional to the size, based on the Cochran's formula, 300 teachers (179 females and 121 males) were selected. In this study, three questionnaires were used to collect data.

1) Spence and Robbins’ Workaholism Inventory (1992): This inventory includes 20 questions and 3 components including work involvement (6 questions), feeling of being driven to work (7 questions), and work enjoyment (7 questions). This inventory is designed based on a 5-point Likert type scale and is scored from 1 (totally disagree) to 5 (totally agree).

2) Williams and Anderson's Organizational Citizenship Behavior Questionnaire (1991): This survey contains 14 items which examine organizational citizenship behavior. This scale is designed based on a 5-point Likert type scale and is scored from 1 (completely disagree) to 5 (completely agree).

3) Linz Questionnaire on Organizational Commitment (2007): This Inventory includes 7 items that investigate employees' organizational commitment. This scale is designed based on a 5-point Likert type scale and is scored from 1 to 5 ( 1 = totally disagree to 5 = totally agree).

To determine the reliability of these questionnaires, Cronbach's alpha coefficient was used, the results of which are presented as follows: work involvement (0.641), feeling of being driven to work (0.619), work enjoyment (0.644), workaholism (0.671), organizational commitment (0.814), and organizational citizenship behavior $(0.76)$. The obtained data was analyzed in both descriptive and inferential levels. In the descriptive level, frequency, percentage, mean, and standard deviation were used and in the inferential level, to examine the research questions, Pearson correlation coefficient and simultaneous multiple regression analysis were applied using SPSS $_{21}$.

\section{Results}

To realize the descriptive status of variables under study, mean and standard deviation are used, the results of 
which are presented in Table 1. These findings indicate that teachers' mean scores on all the variables under study are higher than the considered theoretical mean.

To answer the first research question, i.e. what is the relationship between workaholism and teachers' organizational commitment?, Pearson correlation coefficient and simultaneous multiple regression analysis were used, the results of which are presented in Table 2 and Table 3.

Based on the results demonstrated in Table 2, all correlation coefficients of workaholism and its three components (work involvement, feeling of being driven to work, and work enjoyment) with organizational commitment are significant and positive $(p<0.01)$. Therefore, it is confirmed that workaholism and its components are significantly and positively related to teachers' organizational commitment. It can be concluded that with an increase in teachers' workaholism, their organizational commitment increases. To predict teachers' organizational commitment based on the components of workaholism, simultaneous multiple regression analysis was used, the results of which are presented in Table 3 .

Based on Table 3, the amount of F (122.59) is significant at the level of 0.000 . Therefore, the null hypothesis, i.e. the regression is not significant, is rejected at the 0.99 confidence level and it is confirmed that the linear regression model fits. According to the regression model, the coefficient of determination of $\mathrm{R}^{2}$ is equal to 0.562 , indicating that workaholism can explain $56.2 \%$ of the variance of organizational commitment. Moreover, beta coefficient demonstrates that with a unit increase in work involvement, organizational commitment increases 0.361 , with a unit increase in feeling of being driven to work, organizational commitment increases 0.272 , and with a unit increase in work enjoyment, organizational commitment increases 0.459 .

To answer the second research question, i.e. what is the relationship between workaholism and teachers' organizational citizenship behavior?, Pearson correlation coefficient and simultaneous regression analysis were applied, the results of which are presented in Table 4 and Table 5.

Table 1. Descriptive status of the variables under study.

\begin{tabular}{ccc}
\hline Variable & M (from 5) & SD \\
\hline Work involvement & 3.81 & 0.71 \\
Feeling of being driven to work & 3.34 & 0.64 \\
Work enjoyment & 3.55 & 0.79 \\
Workaholism & 3.51 & 0.48 \\
Organizational commitment & 3.67 & 0.72 \\
Organizational citizenship behavior & 3.84 & 0.62 \\
\hline
\end{tabular}

Table 2. Correlation coefficients of workaholism (and its components) with teachers' organizational commitment.

\begin{tabular}{ccc}
\hline Variable & \multicolumn{2}{c}{ Organizational commitment } \\
\cline { 2 - 3 } Work involvement & $\mathrm{R}$ & Sig \\
\hline Feeling of being driven to work & 0.518 & 0.000 \\
Work enjoyment & 0.421 & 0.000 \\
Workaholism (the overall index) & 0.567 & 0.000 \\
\hline
\end{tabular}

Table 3. Results of regression analysis conducted to predict organizational commitment based on components of workaholism.

\begin{tabular}{ccccccc} 
& \multicolumn{2}{c}{ Non-Standard coefficients } & Standard coefficients & \multirow{2}{*}{ T } & Sig \\
\cline { 2 - 4 } & $\mathbf{B}$ & Std. error & Beta & 0.361 & 8.83 & 0.000 \\
Work involvement & 0.366 & 0.041 & 0.272 & 6.73 & 0.000 \\
Feeling of being driven to work & 0.307 & 0.046 & 0.037 & 0.459 & 11.45 & 0.000 \\
Work enjoyment & 0.42 & $\mathbf{F}=\mathbf{1 2 2 . 5 9}$ & Sig $=\mathbf{0 . 0 0 0}$ & \\
\hline
\end{tabular}


Table 4. Correlation coefficients of workaholism (and its components) with teachers' organizational citizenship behavior.

\begin{tabular}{ccc}
\hline Variable & \multicolumn{2}{c}{ Job burnout } \\
\hline Work involvement & $\mathrm{R}$ & Sig \\
\hline Feeling of being driven to work & 0.523 & 0.000 \\
Work enjoyment & 0.442 & 0.000 \\
Workaholism (the overall index) & 0.489 & 0.000 \\
\hline
\end{tabular}

Table 5. Results of regression analysis conducted to predict organizational citizenship behavior based on components of workaholism.

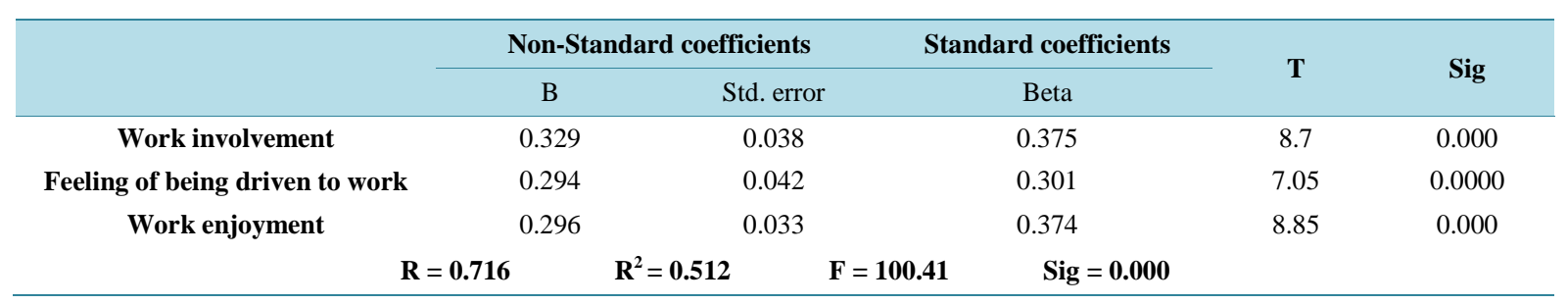

Based on the results demonstrated in the above table, all correlation coefficients of workaholism and its three components (work involvement, feeling of being driven to work, and work enjoyment) with organizational citizenship behavior are significant and positive $(p<0.01)$. Therefore, it is confirmed that workaholism and its components are significantly and positively related to teachers' organizational citizenship behavior. It can be concluded that with an increase in teachers' workaholism, their organizational citizenship behavior increases. To predict teachers' organizational citizenship behavior based on the components of workaholism, simultaneous multiple regression analysis was used, the results of which are presented in Table 5.

Based on the above table, the amount of F (100.41) is significant at the level of 0.000. Therefore, the null hypothesis, i.e. the regression is not significant, is rejected at the 0.99 confidence level and it is confirmed that the linear regression model fits. According to the regression model, the coefficient of determination of $\mathrm{R}^{2}$ is equal to 0.512, indicating that workaholism can explain 51.2\% of the variance of organizational citizenship behavior. Moreover, beta coefficient demonstrates that with a unit increase in work involvement, organizational citizenship behavior increases 0.375 , with a unit increase in feeling of being driven to work, organizational citizenship behavior increases 0.301, and with a unit increase in work enjoyment, organizational citizenship behavior increases 0.374 .

\section{Discussion}

The results of the current study indicated that workaholism and its components (work involvement, feeling of being driven to work, and work enjoyment) were significantly and positively related to teachers’ organizational commitment. Moreover, the results of simultaneous multiple regression analysis demonstrated that all three components of workaholism could predict teachers' organizational commitment. These findings showed that with an increase in teachers' workaholism, their organizational commitment increased and vice versa. These results are in line with the results of Bonebright, Clay and Ankenmann (2000), Burke (2004), Naughton (1987), Sharifi, Salimi, and Ahmadi (2010), Seyed Javadian, Nargesian, and Abbasshahi (2010), Gholipur, Nargeseyan, and Tahmasbi (2008), Enaiati, Shekari, Tahmasbi, Ghaffari, and Shabani (2012). To explain these results, it can be noted that workaholic teachers are eager to work and they are greatly interested in their work. This leads them to devote a lot of time and energy to their work. These people enjoy their work and have a positive feeling about it. This leads them to involve themselves in their work. They usually think about what they do and have a great strong tension towards their work against which they cannot resist. Even when they are not working, they feel guilty. Overtime work is another indicator of these people's innermost desire. Workaholic teachers have been accustomed to their work. They consider their job interesting, challenging, diverse and creative and they are eager to participate in job-related decision makings and accept new job responsibilities, all of which may increase their organizational commitment. According to the results of Burke (2004), workaholics are more com- 
mitted to the organization. Workaholism is related to high workload and overtime work; therefore, workaholics’ commitment to their organizational decreases the organizations' anomalies. Some researchers stated that various types of behavioral patterns of workaholism potentially have different history and are correlated with job performance, job outcomes, and life. The results of Sharifi et al. indicated that various personality dimensions, including extraversion and conscientiousness, were significantly and positively related to organizational commitment. Other words, people who are really active establish many interactions and always think of performing their occupational responsibilities and they are usually more committed to the organization in which they work. It can be expected that these people, compared to others, are more addicted to their job.

The findings confirmed that work involvement was significantly and positively correlated with organizational commitment. Work involvement increase organizational commitment in an organization. Scott et al. believed that work involvement can be defined as normative beliefs about the value of work in one's personal life. Work involvement indicates one's interest and mental, cognitive, and psychological involvement with his/her job. It demonstrates the importance of a job to a person. When a person is involved with his/her work, he/she enjoys his/her job and does not become tired. Job involvement is positively correlated with some variables including organizational commitment, organizational citizenship behavior, motivation and performance and is negatively related to absenteeism and turnover (Mudrack, 2004). Based on the results, people who are more involved with their work spend more time in their workplace; therefore, they are more committed to their organizations. Since workaholics are involved with their work, they devote a lot of time to the work. The results of Seyed Javadian et al. (2010) showed that there was a positive significant relationship between work involvement and organizational commitment. This means that people who are involved with their work are more satisfied with their work, have a positive attitude towards their job and are more committed to the organization and their colleagues. Bonebright et al. (2000) stated that one of the most important features of workaholism was devoting a lot of time to occupational activities which may increase organizational commitment. The results of Gholipur et al. (2008) indicated that there was a positive and significant relationship between work involvement and organizational commitment. These findings are consistent with the results of the current study indicating that due to high levels of work involvement in these people, their organizational commitment is higher compared to others.

With regard to the results of the current study, feeling of being driven to work increases organizational commitment. To explain this result, it can be noted that since workaholism is considered as a type of commitment to work, it can be expected that teachers who feel more driven to work have higher levels of organizational commitment. Workaholics usually think about their occupational activities and experience a strong tension towards their work, against which they cannot resist (Smith \& Seymour 2004). This aspect of workaholism has presented in various studies as an implicit and implied component. For example, Scott et al. (1997) believed that workaholism is thinking persistently about work even when the individual is not doing the job. Oates (1971) stated that workaholism was an uncontrollable need to work. Naughton (1987) and Spence and Robbins (1992) asserted that workaholism was an inner urge to work hard. McMillan, Brady, O’Driscoll, and Marsh (2002) considered feeling of being driven to work as an inherent and inner push toward work and stated that rather than external pressure, the work was done due to an internal tendency. In a study, Sharifi et al. (2010) demonstrated that people who were conscientious had higher levels of organizational commitment. Therefore, it can be expected that these people have a greater tendency towards work and as a result are more committed to their work and the organization.

Bonebright et al. (2000) considered the concept of extreme joy for this condition. Spence and Robbins (1992) also proposed work enjoyment as one of the main aspects of workaholism. According to Kantro (1979), workaholics seek work involvement and work enjoyment. Generally, it can be stated that people who work really hard often used the term entertainment to describe their work. Mac Millan et al. (2002) considered work enjoyment as a level of satisfaction from doing a job which is related to job satisfaction. In a study conducted by Rezaee (2000), examining the relationship between job satisfaction and organizational commitment, the results indicated that there was a significant and positive relationship between job satisfaction and organizational commitment. Indeed, people who are more satisfied with their work, compared to others, enjoy their work more and spend more time on their work. Spending more time in the organization shows that there are more committed to the organization, compared to others. Hosseinian et al. (2007), in a study conducted to examine internal organizational factors affecting the development of organizational commitment, concluded that the nature of working in an organization increases employees' organizational commitment. Since the type, nature and attractiveness play significant roles in employees’ productivity and performance, employees for whom the type of activity in 
the organization is attractive are more willing to do the job and as a result they are more committed to the organization.

Other findings of the current study indicated that workaholism and its components (work involvement, feeling of being driven to work, and work enjoyment) were significantly and positively correlated with organizational citizenship behavior. Moreover, the results of simultaneous multiple regression analysis demonstrated that all three components of workaholism could predict teachers' organizational citizenship behavior. These results showed that with an increase in teachers' workaholism, their organizational citizenship behavior increased and vice versa. These findings are in line with the results of Spence and Robbins (1992), Gorgievski, Bakker, \& Schaufeli (2010), Taris, Geurts, Schaufeli, Blonk, \& Lagerveld (2008), Burke (2004), Snir and Harpaz (2004), Karasek and Theorell (1990), Ahmadi, Tahmabi, Babashahi and Fatahi (2010), Khaef Elahi, Nargesian, and Babashahi (2012), Ziaee and Nargesian (2012). To explain these results, it can be noted that since workaholic teachers' degree of work involvement is high, they feel a great tension towards their work and enjoy it; hence, they have a better level of organizational citizenship behavior including optional behaviors which are not among their formal responsibilities and are not directly considered by school and Department of Education. Teachers believe that these behaviors increase the overall effectiveness of the school; therefore, they conduct them. Empirical research conducted to predict factors leading to organizational citizenship behavior put an emphasize on some personality characteristics, including workaholism, which aid an individual to be motivated with a strong inner desire rather than external motivators (Spence \& Robbins, 1992). Workaholics work harder and harder to achieve more success. Work involvement aids people to feel energetic and emotionally connected to their work, such that it provides the ground for working harder and enjoying the work more (Gorgievski et al., 2010). The study of Taris et al. (2008) demonstrated that workaholism may lead to spend a lot of energy and time much more than what the employee expected and committed to do and lead people to participate more in the work. A study conducted by Ahmadi et al. (2010) indicated that workaholics have high levels of life satisfaction, job performance, and organizational citizenship behavior and have low levels of stress and voluntary turnover.

The findings confirmed that work involvement was significantly and positively correlated with organizational citizenship behavior. To explain this result, it can be stated that teachers who are involved with their work and their interests are in line with the goals of their work, feel respected when they do their job well and as a result they display better organizational citizenship behavior. More involvement with the work is accompanied with greater conscientiousness in the organization and people who are so obsessed with their work voluntarily devote a lot of time to the activities related to work (Snir \& Harpaz, 2004). In fact, work involvement improves employees' cognitive engagement with their work and enhances their mental health, so that it encourages the employees to participate more in the organization (Burke, 2004). Some researchers believe that workaholics have a great authority in decision-making and have high control over their jobs. These are considered as important factors aiding to decrease work pressure and increase job satisfaction, organizational commitment and finally organizational citizenship behavior (Karasek \& Theorell, 1990). These studies indicated that having control over the job can moderate the impacts of workaholism. In fact, these studies considered having control over the job as a significant factor in the relationship between workaholism and health symptoms which increases employees' level of participation, aids the organization to achieve its goals and improves employees' attachment and commitment to the organization. In addition, Karasek (1979) demonstrated that if employees are allowed to control their work and the variable of control on the job is considered, employees will experience less stress and feel more committed to their job and organization.

The findings confirmed that feeling of being driven to work may lead to organizational citizenship behavior. Workaholic teachers often think about their occupational activities and feel a great tension towards their work against which they cannot resist. Even when they are not at work, they think of work and as a results they attempt to conduct behaviors such as altruism, consciousness, forgiveness, magnanimity, and civic virtue which are all components of organizational citizenship behavior. Consistent with these results, the findings of the current study indicated that workaholics are more task-oriented rather than result-oriented. Other words, these people put a great emphasis on the processes rather than the results. In fact, positive approach to workaholism creates an inner desire to work long hours (Makenzi et al. 2005). However, it should be considered that workaholics mainly search for satisfaction and joy in their work (Bozorgmehri, 2009).

\section{Conclusions}

Finally, results indicated a significant positive correlation between work involvement and incident of organiza- 
tional behavior. To explain this finding, it can be mentioned that teachers who enjoy their work dedicate more time to it and value their work at school. As a result, they display more organizational citizenship behavior. In fact, formation of positive emotions in workaholics leads them towards more participation in the organization, i.e. since workaholics love their job and enjoy it, they put a great effort in their work and attempt to aid the organization to achieve its goals (Schaufeli, Tarri, \& Rhenen, 2008). Additionally, the results of Podsakoff, Mackenzie, Paine and Bachrach (2000) show that performing tasks which are satisfying creates more joy and as a result leads to the incident of organizational citizenship behavior. According to the obtained results, the following recommendations are provided.

Since schools and educational organizations, due to their challenging and diverse educational content, are considered as a suitable ground for development and formation of workaholism, paying great attention to this phenomenon in these organizations seems essential. In the current study, it was determined that teachers' mean score on workaholism was higher than the considered mean. Therefore, holding educational courses aiming at helping teachers to become familiar with workaholism, various aspects of this concept, and the methods of managing it in the mentioned organizations is highly recommended. With regard to the positive and significant relationship of workaholism with teachers' organizational commitment and organizational citizenship behavior, to support the behaviors associated with workaholism in the organizational environment, these behaviors should be rewarded; since they indirectly provide the ground for sustained organizational commitment, and as a result, conduct voluntary behaviors. Moreover, when assigning organizational tasks and missions, people's inner desire should be considered. Additionally, when designing a job, its attraction should be considered such that it should have inner attraction for an employee and create passion and desire for the individual to do the job.

\section{References}

Afkhami Ardakani, M., \& Farahi, R. (2012). Knowledge Workers’ Culture, Organizational Commitment and Desire to Leave Their Work: Design an Explanation Model in the Research Institute of Petroleum Industry. Science of Management, 6, 124.

Ahmadi, P., Tahmabi, R., Babashahi, J., \& Fatahi, M. (2010). The Role of Personality Factors in Work Holism Formation. Transformation Management Journal, 2, 46-67. (Text in Persian)

Allen, N. J., \& Meyer, J. P. (1990). The Measurement and Antecedents of Affective, Continuance and Normative Commitment to the Organization. Journal Occupational Psychology, 63, 1-18. http://dx.doi.org/10.1111/j.2044-8325.1990.tb00506.x

Bennett, N., \& Masholder, K. (1997). Cohesiveness and Organizational Citizenship Behavior. Academy of Management Journal, 19, 163-72.

Bonebright, C. A., Clay, D. L., \& Ankenmann, R. D. (2000). The Relationship of Workaholism with Work-Life Conflict, Life Satisfaction, and Purpose in Life. Journal of Counseling Psychology, 47, 469-477. http://dx.doi.org/10.1037/0022-0167.47.4.469

Burke, R. J. (2004). Introduction: Workaholism in Organizations. Journal of Organizational Change Management, 17, 420423.

Enaiati, G. R., Shekari, G. H., Tahmasbi, R., Ghaffari, H., \& Shabani, M. (2012). Examining the Relationship between Workaholism and Organizational Commitment. Management and Development Process, 25, 93-114.

Gholipur, A., Nargeseyan, A., \& Tahmasbi, R. (2008). Workaholism: The New Challenge of Human Resource Management. Danesh e Modiriyat, 21, 91-110. (Text in Persian)

Gorgievski, M. J., Bakker, A. B., \& Schaufeli, W. B. (2010). Work Engagement and Workaholism: Comparing the SelfEmployed and Salaried Employees. Journal Positive Psychology, 5, 83-96. http://dx.doi.org/10.1080/17439760903509606

Karasek, R. A. (1979). Job Demands, Job Decision Latitude, and Mental Strain: Implications for Job Redesign. Administrative Science Quarterly, 24, 285-308. http://dx.doi.org/10.2307/2392498

Karasek, R. A., \& Theorell, T. (1990). Healthy Work: Stress, Productivity and the Reconstruction of Working Life. New York: Basic Books.

Khaef Elahi, A. A., Nargesian, A., \& Babashahi, J. (2012). Investigating the Relationship between Workaholism and Organizational Citizenship Behavior (Case of: Nurses in Tehran City). Transformation Management Journal, 4, 21-37. (Text in Persian)

Madani, H., \& Zahedi, M. J. (2005). Determining the Priority of Factors Affecting Organizational Commitment. Sociology of Iran, 6, 3-33. 
McMillan, L. H. W., Brady, E. C., O’Driscoll, M. P., \& Marsh, N. V. (2002). A Multifaceted Study of Spence and Robbins’ (1992) Workaholism Battery. Journal of Occupational and Organizational Psychology, 75, 357-368. http://dx.doi.org/10.1348/096317902320369758

Mudrack, P. E. (2004). Job Involvement, Obsessive-Compulsive Personality Traits, and Workaholic Behavioral Tendencies. Journal of Organizational Change Management, 17, 490-508. http://dx.doi.org/10.1108/09534810410554506

Naughton, T. J. (1987). A Conceptual View of Workaholism and Implications for Career Counselling and Research. Career Development Quarterly, 35, 180-187. http://dx.doi.org/10.1002/j.2161-0045.1987.tb00912.x

Oates, W. (1971). Confessions of a Workaholic: The Facts about Work Addiction. New York: World Publishing Co.

Organ, D. W. (1998). Organizational Citizenship Behavior: The Good Soldier Syndrome. Lexington, MA: Lexington Books.

Podsakoff, P. M., Mackenzie, S. B., Paine, J. B., \& Bachrach, D. G. (2000). Organizational Citizenship Behavior: A Critical Review of the Theoretical and Empirical Literature and Suggestions for Future Research. Journal of Management, 6, 513563. http://dx.doi.org/10.1177/014920630002600307

Robbins, S. P., \& Judge, T. A. (2007). Organizational Behavior (12th ed.). Upper Saddle River, NJ: Prentice Hall.

Schaufeli, W. B., Tarris, T. W., \& Rhenen, W. V. (2008). Workaholism, Burnout, and Work Engagement: Three of a Kind or Three Different Kinds of Employee Well-Being? Applied Psychology: An International Review, 57, 173-203. http://dx.doi.org/10.1111/j.1464-0597.2007.00285.X

Scott, K. S., Moore, K. S., \& Miceli, M. P. (1997). An Exploration of the Meaning and Consequences of Workaholism. Human Relations, 50, 287-314. http://dx.doi.org/10.1177/001872679705000304

Seyed Javadian, S. R., Nargesian, A., \& Abbasshahi, J. B. (2010). Examining the Relationship between Work Involvement and Characteristics of Users' Behavior. Managerial Perspective, 1, 47-62.

Sharifi, S., Salimi, G. A., \& Ahmadi, S. A. (2010). Examining the Relationship between Personality Characteristics and Organizational Commitment among Managers and Elementary School Teachers. A New Approach in Educational Management, 1, 81-106.

Smith, D. E., \& Seymour, R. B. (2004). The Nature of Addiction. In R. H. Coombs (Ed.), Handbook of Addictive Disorders: A Practical Guide to Diagnosis and Treatment (pp. 3-30). Hoboken, NJ: John Wiley \& Sons, Inc.

Snir, R., \& Harpaz, I. (2004). Attitudinal and Demographic Antecedents of Workaholism. Journal of Organizational Change Management, 17, 520-536. http://dx.doi.org/10.1108/09534810410554524

Spence, J. T., \& Robbins, A. S. (1992). Workaholism: Definition, Measurement, and Preliminary Results. Journal of Personality Assessment, 58, 160-178. http://dx.doi.org/10.1207/s15327752jpa5801_15

Taris, T. W., Geurts, S. A. E., Schaufeli, W. B., Blonk, W. B., \& Lagerveld, S. E. (2008). All Day and All of the Night: The Relative Contribution of Two Dimensions of Workaholism to Well-Being in Self-Employed Workers. Work and Stress, 22, 153-165. http://dx.doi.org/10.1080/02678370701758074

Ziaee, S., \& Nargesian, A. (2012). Examining the Relationship between Workaholism and Organizational Citizenship Behavior among Members of the Faculty of Physical Education and Sports Teachers in Tehran. Sport Management, 4, 86-105. 